\title{
The relationship between foreign direct investment and GDP in Cameroon (2000-2020)
}

\author{
L.P. Numbu ${ }^{1,2} \bowtie$, Zh.S. Belyaeva ${ }^{1}$ \\ ${ }^{1}$ Ural Federal University, Ekaterinburg, Russia; resor199494@gmail.com \\ ${ }^{2}$ Gadget Zone 237, Yaounde, Cameroon
}

\section{ABSTRACT}

Relevance. In the last 20 years Cameroon has faced a series of crises. The 2035 governmental programme of recovery aims to transform the country into an emerging economy nation. The effects of the COVID-19 pandemic have slowed down economic growth in Cameroon and the country is hoping to attract foreign direct investment (FDI) and thus benefit from the new business opportunities to revitalize its economy. This context makes the research on the relationship between FDI and GDP particularly relevant.

Research objective. This paper is designed to assess the relationship between GDP and FDI in Cameroon in 2000-2020. In addition, we aim to assess the scope of internationalization through FDI as a possible catalyst for economic recovery. Data and methods. The paper uses correlation and regression analysis to show the relationship between FDI and GDP.

Results. The results show that FDI can increase Cameroon's GDP and may be used as an empirical basis for policy- and strategy-making in Cameroon.

Conclusions. We found a strong correlation between FDI and GDP in Cameroon for a 21-year period. This result is supported by the double effect of FDI on the national economy: FDI directly affects the investment component of GDP, but it also influences economic growth indirectly. The activities of foreign firms in Cameroon can support trade and even balance of payment, which indirectly influences the export and import component of GDP. Foreign subsidiaries both solely owned or joint ventures pay indirect taxes to the government and thus influence government spending.
\end{abstract}

\section{KEYWORDS}

foreign direct investment, GDP, global pandemic crisis recovery, Cameroon, business environment

\section{FOR CITATION}

Numbu, L.P., \& Belyaeva, Zh.S. (2021). The relationship between foreign direct investment and GDP in Cameroon (2000-2020). R-economy, 7(3), 200-209. doi: 10.15826/recon.2021.7.3.018

\section{Связь между прямыми иностранными инвестициями и ВВП в Камеруне (2000-2020)}

\author{
Л.П. Нумбу ${ }^{1,2}$, Ж.С. Беляева ${ }^{1}$ \\ ${ }^{1}$ Уральский федеральный университет, Екатеринбург, Россия; tresor199494@gmail.com \\ ${ }^{2}$ Gadget Zone 237, Яунде, Камерун
}

\section{АННОТАЦИЯ}

Актуальность. За последние 20 лет Камерун столкнулся с серией кризисов. Правительственная программа восстановления на 2035 г. направлена на превращение страны в страну с развивающейся экономикой. Последствия пандемии COVID-19 замедлили экономический рост в Камеруне, и страна надеется привлечь прямые иностранные инвестиции (ПИИ) и, таким образом, извлечь выгоду из новых деловых возможностей для оживления своей экономики. Этот контекст делает исследование взаимосвязи между ПИИ и ВВП особенно актуальным.

Цель исследования. Исследование направлено на оценку взаимосвязи между ВВП и ПИИ в Камеруне в 2000-2020 гг. Кроме того, мы стремимся оценить масштабы интернационализации через прямые иностранные инвестиции как возможный катализатор восстановления экономики.

Данные и методы. В документе используется корреляционный и регрессионный анализ, чтобы показать взаимосвязь между ПИИ и ВВП.

\section{КЛЮЧЕВЫЕ СЛОВА}

прямые иностранные инвестиции, ВВП, выход из глобального пандемического кризиса, Камерун, бизнес-среда 
Результаты. Результаты показывают, что прямые иностранные инвестиции могут увеличить ВВП Камеруна и могут использоваться в качестве основы для разработки политики и стратегии в Камеруне.

Выводы. Мы обнаружили сильную корреляцию между ПИИ и ВВП в Камеруне за 21-летний период. Этот результат подтверждается двойным влиянием ПИИ на национальную экономику: ПИИ напрямую влияют на инвестиционную составляющую ВВП, но также косвенно влияют на экономический рост. Деятельность иностранных фирм в Камеруне может поддерживать торговлю и даже платежный баланс, что косвенно влияет на экспортно-импортную составляющую ВВП. Иностранные дочерние компании, находящиеся в единоличной собственности или совместные предприятия, платят косвенные налоги государству и, таким образом, влияют на государственные расходы.

\section{ДЛЯ ЦИТИРОВАНИЯ}

Numbu, L.P., \& Belyaeva, Zh.S. (2021). The relationship between foreign direct investment and GDP in Cameroon (2000-2020). R-economy, 7(3), 200-209. doi: 10.15826/recon.2021.7.3.018

\section{Introduction}

Developing countries, including Cameroon, seek foreign direct investment (FDI) to stimulate their economic development. Cameroon strives to gain the status of emerging economy by 2035 . Over the past decades, the country's government has made substantial effort to improve the investment climate and attract foreign investors. The country's economic performance has also improved considerably since the mid-1990s. Although the current value of FDI into Cameroon is still below the projected values (Stephane, 2020), several potential investors have described Cameroon as not the best country to invest in (Efiong, 2013) in terms of the ease of doing business, taxes and political insecurity.

The current global pandemic has had its toll on nearly every nation, and while the full extent of its effects is yet to be established, many businesses in Cameroon have been trying to mobilize their resources to survive the pandemic. The current health crisis hit Cameroon at the time when the country was struggling to resolve the ongoing armed conflict in the English-speaking territories. The Anglophone crisis has led to similar effects on the economy as the COVID-19 crisis. Both crises have led to increased mortality rates and, as the government was trying to minimize the damage, to the restrictions on movement, social distancing, and lockdowns. Another problem was the falling foreign investment due to the above-described events. However, while the Cameroonian problems are known and their impact has tainted the country's reputation both internally and externally, there is a number of positive aspects which are mostly unknown to foreign investors. The government has substantially improved its FDI framework and has moved its primary focus from the natural resources sector to the service and manufacturing industries.
There are three standard types of FDI defined in theory: efficiency-seeking, market-seeking and resource-seeking FDI (Dunning, 2000). Cameroon receives mainly market and resource seeking FDI as the nation has a growing economy and has fertile land and abundant resources attractive for several foreign manufacturing companies.

There are certain differences in the factors that shape FDI into developing countries in Sub-Saharan Africa (SSA) and in other regions (Jaiblai, 2019). While high return on capital and infrastructural development boost FDI in non-SSA countries, these factors have no impact on the situation in SSA countries. Trade openness alone promotes FDI in both SSA and non-SSA (Asiedu, 2002). According to Suliman (2009), the determinants of FDI to Africa are GDP growth, openness, international reserves, literacy rate, freedom (political and civil rights), natural resources, and war. Thus, it is necessary to create policies depending on what is best to attract FDI.

All of the above explains the purpose of our research, which is aimed to evaluate the positive payoff from FDI, and address the question as to whether FDI can be a catalyst for the country's economic recovery. This study will focus on the relationship between GDP and FDI and the question as to how this relationship defines the national strategy until 2035: for the period of 2020-2027 the government is planning to turn Cameroon into a middle-income country and for 2028-2035, to turn it into an emerging market economy.

\section{Theoretical framework}

The following part examines a set of proposed variables based on the research on the effects of FDI. The current situation of the military conflict in Cameroon (Simpeh, 2019; Agwanda, 2020) is a suitable example of an internal crisis. The 
COVID-19 pandemic that is ravaging the world (Naveen, 2020) is an external crisis.

In our study, we intend to look at the relationship between GDP and FDI. Gross domestic product (GDP) is considered to be the main indicator of economic growth (Tim, 2020) in a particular country at a given time. GDP is universally defined as the monetary value of all final goods and services manufactured in a given territory. GDP levels can be influenced by different factors and variables both internal and external to national economy: e.g. consumption levels, education rates, unemployment rate, the number of firms, trade openness, foreign direct investment and volume of remittances.

Foreign direct investment is the money/resources directly injected into the national production of goods and services by a company located overseas. It can be done either by buying or by expanding the operations of an existing business in the target country (Arafatur, 2015). FDI is most often considered to be a growth catalyst and it has received increasing attention in developing and less developed countries in recent years. It is beneficial to every nation becomes it contributes to economic growth in terms of technology, skilled labor, and transfer of skills (Acemoglu, 2006; Nadeem, 2014).

Drawing from the study by Sun (2002), in an era of increased economic globalization, FDI is a significant driving force behind the interdependence of national economies especially of developing nations. Alam (2013) examined the potential determinants of FDI with the help of a panel data set of ten OECD member countries (1985-2009). The Granger causality test was used to identify short- and long-run causalities between FDI and all the variables that were proven to be significant determinants of FDI through regression analysis. The results indicate that the labor cost, quality of infrastructure and market size are the factors that influence FDI. According to modern economists, FDI has the potential to be helpful to increase GDP of developing economies (Ajayi, 2006). This assumption relies on the fact that FDI will effectively contribute to the countries' growth and will help expand their domestic markets.

Kang (2011) used regression analysis to study the bi-directional link between FDI and economic growth in Cameroon for 1980-2009 and showed a highly positive relationship between FDI and economic development. It was also established that FDI is more efficient than domestic investment in boosting economic growth. Forcha (2009) looked at the connection between FDI and economic performance of Cameroon in 1970-2007. Based on the OLS technique and the cointegration error correction mechanism (unit roots test), it was found that FDI positively responds to industrialization. The study indicates that FDI significantly impacts the economic performance of Cameroon and reacts rapidly to growth than any other variable. Hakizimana (2015) investigated the relationship between FDI and Rwanda's GDP per capita and found a positive relationship between FDI and GDP. Hassen (2012) examined the impact of FDI on Tunisia's economic growth by using the data for 1975-2009 and found that FDI could boost long-term economic growth. The examination of FDI in Kenya as the main driver for real GDP growth shows that FDI is mainly related to the situation in the market such as good infrastructure, political stability, market size and low corruption levels (Abala, 2014).

Wakyereza (2017) studied the impact of FDI on employment, poverty reduction and economic growth in Uganda in 1985-2014 by using the Vector AutoRegressive (VAR) and Ordinary Least Squares (OLS) and found that FDI has a positive influence on all the three indicators. Suleiman (2013) used dynamic OLS for SACU countries (Botswana, Lesotho, Namibia, South Africa, and Swaziland) and founnd that FDI's impact on economic growth was significant and dynamic. Among many others, Ngeny (2014) investigated the influence of FDI on Kenya's development, using time series data for 1970-2011. The findings from this study confirms that FDI has a positive effect on growth. Stoneman (1975) investigated the role of FDI on the economic growth of developing nations and his results indicate that FDI increases productivity levels as a result of higher capital stock and improves the balance of payment position of the host countries. In the paper to actualize the impact of savings and FDI on economic growth in emerging Asian economies, a VECM (Vector Error Correction Mechanism) was applied by Bayar (2014) on the data for 1982-2012. A long-run positive relationship was then established between FDI and economic growth. In the same vein, Faruk (2012) showed that FDI has a more considerable impact on economic growth by using the OLS technique to investigate the effect of FDI on the growth of the Bangladeshi economy for 1980-2011. 
Gupta (2015) applied the regression analysis method to assess the impact of FDI on India's economic growth by using secondary data for 2000-2013 and showed that FDI needs three years to start boosting economic growth. Yusuf (2020) uses the dynamic fixed effect technique to study the impact of FDI, financial development, political instability and democracy on economic growth in West Africa for 1996 to 2016. No significant relationship was found in the short run although the study detected a significant positive relationship in the long run for the coefficient of FDI. Agya (2014) explored the effect of FDI on China's economic growth, using the data for 1995-2010 and the Granger causality test. It was found that FDI does not in any way cause economic growth in the primary industry.

Cameroon's twin crisis means that as the nation lacks resources to tackle the problems, there is a need for external assistance (Forgha, 2009). Cameroon's twin crisis is an exogenous shock that affects the territory through several different transmission paths. World trade is today undergoing its fastest decline in many decades. FDI and remittances are plummeting significantly. Cameroon is not in a favorable position to address the consequences of the current economic crisis. International support to mitigate the effect of this twin crisis is vital in that it can reduce the possibility of a long-term plan failure by sustaining concessional financing to revive Cameroon's economy. The size and speed of the international response will be vital in determining the impact of the crisis on Cameroon's economic performance. This explains why the volume and the quality of FDI are today increasingly crucial for growth and resilience.

\section{Data and methods}

As noted above, this study relies on the secondary data sources to gather the data for all the variables in question (GDP growth, GDP, FDI, inflation, national debt, and trade openness) for a 20 -year period. The sources we used include IMF reports, the World Bank's database and Trading Economics and Doing Business ranking. Inflation can be captured by GDP deflator; the consumer price index was taken and used as a proxy. Net trade in goods and services was the benchmark indicator for trade openness. The net inflow in FDI was chosen as the main variable. Although in our research more emphasis is given to GDP and FDI, other macroeconomic indicators were considered as well.
At the test phase, we are going to show how FDI can be used to predict the GDP of a nation. To this end, we are going to use four classes of variables. FDI is the primary independent variable (predictor) with the net capital flow as the proxy for FDI. the dependent variable is the economic growth of Cameroon seen as the change in GDP over the years. We also introduce control variables and a dummy (crisis). The national debt level can control the relationship between FDI and economic growth. It was also crucial to include past GDP, trade openness, and inflation.

The path to establishing the relationship between the macroeconomic indicators via the Pearson correlation coefficient was considered to fit best the purpose of this research (1)

$$
\begin{gathered}
E G_{I}=\beta_{0}+\beta_{1} \text { FDI }+\beta_{2} \text { Rem }+\beta_{3} \text { INF }+ \\
+\beta_{4} \mathrm{TO}+\beta_{5} \text { Debt } / \text { GDP }+\beta_{6}(\mathrm{C})+\varepsilon,
\end{gathered}
$$

where $\beta(1,2,3,4,5,6$ and 7$)$ are estimated coefficients, PGDP is the past gross domestic product, TO, trade openness, INF, the rate of inflation, $\mathrm{D} / \mathrm{GDP}$ is the debt to GDP ratio, FDI is foreign direct investment, Rem stands for remittances and C, for crisis.

The Pearson correlation coefficient and the concept of variance are applied to examine the relationship between the macroeconomic indicators in relation to FDI and GDP. Variance explained $\left(R^{2}\right)$ is adopted to identify the strength of the relationship between FDI and Cameroon's GDP, the proportion of GDP explained by FDI. Variance analysis is another method which can be used to show that FDI is a predictor of GDP. In other words, we need to convert the correlation coefficient $(R)$ into the coefficient of determination $\left(R^{2}\right)$ to obtain an indicator that would show the relationship between the variables.

The IMF and World Bank databases are used as reliable sources of global and national data. Other sites such as Trading Economics and Doing Business rankings were also used as source of data for the chosen period.

\section{Results}

The descriptive statistics of the studied variables for 21 years is given in Table 1 .

Descriptive evidence is used to show the trend and relationship between the given macroeconomics indicators via the 21-year time-series data (2000-2020). It should be noted that we took new inflow to measure both FDI and remittance. For the application of natural log that the study 
assumes the value of zero for negative net values. It is for this reason that the minimum values for these multiple variables (FDI and remittances) are taken as zero. It was difficult to obtain the log values of net trade since Cameroon seems to have more imports than exports. In such a scenario, net trade is negative and does not permit the application of natural log to reduce the risk of deviation, which means that the standard deviation is high and the presence of outliers has greater significance. Trade openness, remittances, and national debt as a ratio of GDP also show the risk of deviation or presence of outliers.

It may be difficult to depict the behavior of GDP with respect to changes in FDI since the connection between the two is more complex. The bar in Figure 1 can show fluctuations of GDP from 2000 to 2020 , but the movement in the line graph (FDI) is not very visible, which does not necessarily signify the absence of the relationship between the core variables of the study. It merely implies that GDP values are higher than those of net FDI, and the fluctuations seem small, especially as the values of FDI are net inflow (inflow outflow). Cameroon's GDP appears to be on the rise with just a few noticeable drops in the given period. Despite the Anglophone crisis, Cameroon's GDP maintained the same growth rate for 2018 and 2019 financial year. The explanation may be that the system has developed a kind of a shield that can protect it in the period of crisis. Thus, the effect of the crisis on GDP and its growth will become more pronounced later. This is a sound argument since the impact of the crisis on the economy is not immediate, and the 2020 projection of GDP already indicates a fall in GDP.

Descriptive statistics

Table 1

\begin{tabular}{|l|c|c|c|c|c|}
\hline & $\mathbf{N}$ & Minimum & Maximum & Mean & Standard deviation \\
\hline GDP & 21 & 10.0036 & 10.5884 & 10.376496 & .1879222 \\
\hline Growth in GDP & 21 & 2.0207 & 6.7810 & 4.156516 & 1.1947087 \\
\hline Inflation & 21 & .2336 & 5.3378 & 2.244784 & 1.4373599 \\
\hline FDI (net inflow) & 21 & .0000 & 8.9109 & 8.143258 & 1.9171350 \\
\hline Debt/GDP & 21 & 9.3000 & 75.4000 & 31.723810 & 18.9474978 \\
\hline Remittances (net inflow) & 21 & .0000 & 8.3962 & 6.869806 & 2.8933400 \\
\hline Net trade & 21 & -1121429117.9 & 15600000.0 & 6890415392.9 & 34168534550.0 \\
\hline Crisis & 21 & 0 & 1 & .29 & .463 \\
\hline
\end{tabular}

Source: World Bank (2020). Retrieved from The World bank data Cameroon: https://data.worldbank.org/country/cameroon; IMF (2020, October). International Monetory Fund Cameroon. Retrieved from imf.org: https://www.imf.org/en/Countries/CMR; Trading Economics. (2019). Cameroon GDP. Retrieved from: https://tradingeconomics.com/cameroon/gdp; Doing Business (2020, May). Economy profile Cameroon - Doing Business 2020.

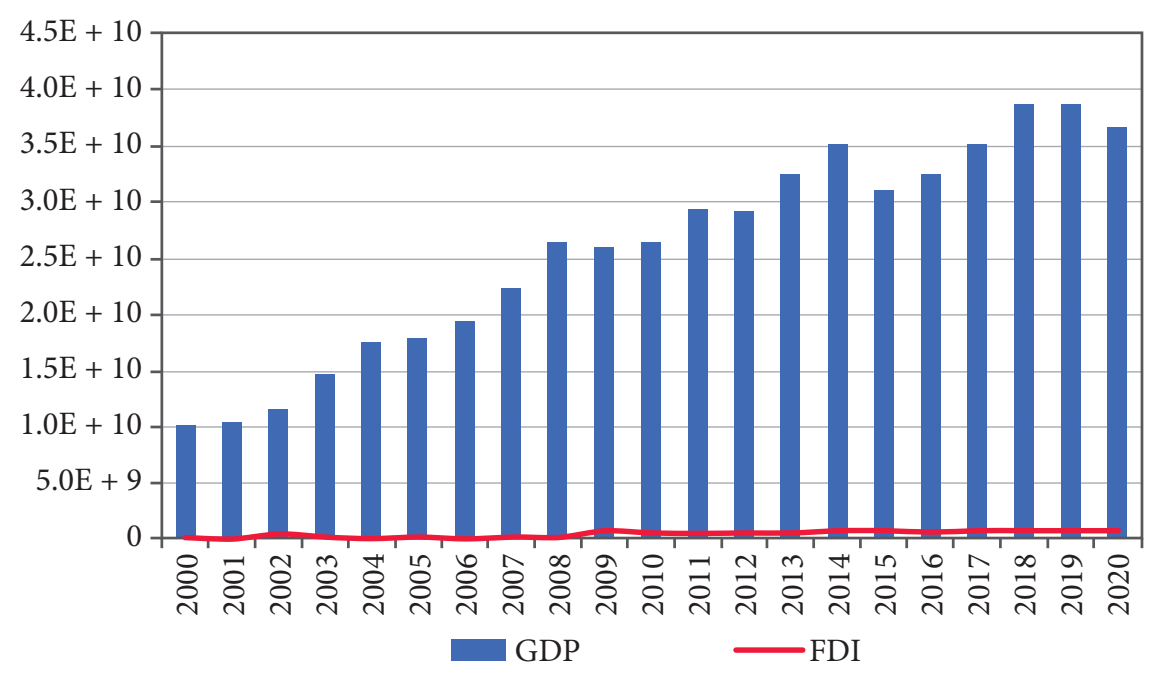

Figure 1. Time series diagram (GDP vs FDI)

Source: Compiled by the authors by using the data from: World Bank (2020). Retrieved from The World bank data Cameroon: https://data.worldbank.org/country/cameroon; IMF (2020, October). International Monetory Fund Cameroon. Retrieved from imf.org: https://www.imf.org/en/Countries/CMR; Trading Economics. (2019). Cameroon GDP. Retrieved from: https://tradingeconomics.com/cameroon/gdp; Doing Business (2020, May). Economy profile Cameroon - Doing Business 2020. 
To ensure visibility, the natural log values for both GDP and FDI are considered alongside GDP growth and the inflation rate in Figure 2.

It is difficult to notice any movement in the natural log values of GDP, although the volatility of the natural log values of FDI is visible. Fluctuations in GDP growth and inflation between 2000 and 2020 are quite clear. Growth of GDP seems to go in the opposite direction to the inflation rate, in other words, these two indicators are inversely related to each other. Our main focus is not on inflation or GDP growth. We intend to follow the dynamics in the relationship between GDP and FDI.

According to the first estimation (Table 2), it's not possible to explain changes of GDP growth by using FDI or any of the other indicators. It has been noted that the inflation rate, which is a percentage change in the prices of consumer goods, is more suitable for estimation of the changes in the growth rate of GDP since both are of the second-order derivatives. Though the relationship between inflation and GDP growth is insignificant, it has a p-value (0.085) that is close to 0.05 level of significance. Therefore, it is better to use GDP rather than the growth rate of GDP. It is best to relate actual FDI to actual GDP since growth is a change over a year and may not be tied to a specific year (since it refers to previous year GDP). The Pearson correlation coefficient $(r)$ is one of the best methods of establishing a relationship between variables.

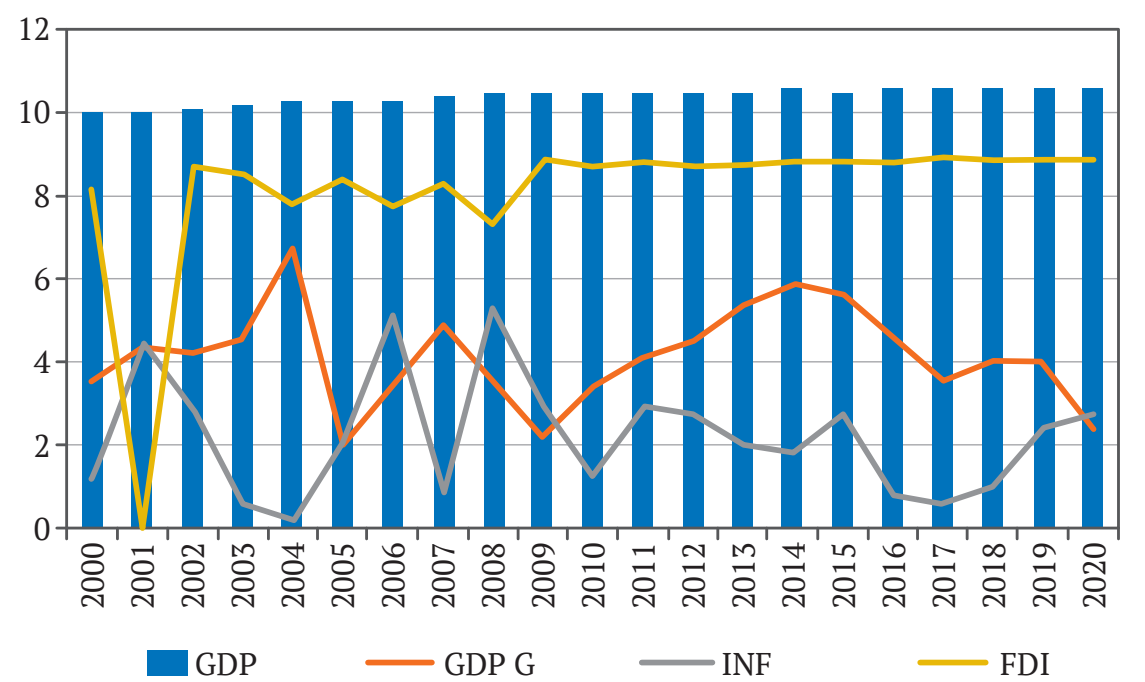

Figure 2. Trend graph (GDP, FDI GDP growth and inflation)

Source: Compiled by the authors by using the data from: World Bank (2020). Retrieved from The World bank data Cameroon: https://data.worldbank.org/country/cameroon; IMF (2020, October). International Monetory Fund Cameroon. Retrieved

from imf.org: https://www.imf.org/en/Countries/CMR; Trading Economics. (2019). Cameroon GDP. Retrieved from: https://tradingeconomics.com/cameroon/gdp; Doing Business (2020, May). Economy profile Cameroon - Doing Business 2020.

Table 2

Estimation Data

\begin{tabular}{|c|l|c|c|c|c|c|c|}
\hline \multicolumn{1}{c|}{ Metric } & \multicolumn{1}{|c|}{ Indicator } & Beta & T-value & P-value & Std.Error & VIF & Comment \\
\hline \multirow{5}{*}{ GDP growth } & FDI & -.195 & -.666 & .516 & .182 & 1.831 & Insignificant \\
\cline { 2 - 9 } & Remittances & -.141 & -.477 & .641 & .147 & 1.866 & Insignificant \\
\cline { 2 - 9 } & Inflation & -.457 & -1.851 & .085 & .246 & 1.306 & Insignificant \\
\cline { 2 - 9 } & Net trade & .528 & 1.429 & .175 & .000 & 2.922 & Insignificant \\
\cline { 2 - 9 } & Debt/GDP & -.074 & -.319 & .755 & .023 & 1.167 & Insignificant \\
\cline { 2 - 9 } & Crisis & -.195 & -.666 & .516 & .603 & 1.831 & Insignificant \\
\cline { 2 - 8 } & R square =6.3 Alpha = 2.921 Significant level = 5\% & & &
\end{tabular}

Source: Compiled by the authors by using the data from: World Bank (2020). Retrieved from The World bank data Cameroon: https://data.worldbank.org/country/cameroon; IMF (2020, October). International Monetory Fund Cameroon. Retrieved from imf.org: https://www.imf.org/en/Countries/CMR; Trading Economics. (2019). Cameroon GDP. Retrieved from: https://tradingeconomics.com/cameroon/gdp; Doing Business (2020, May). Economy profile Cameroon - Doing Business 2020. 
Pearson Correlation

\begin{tabular}{|l|c|c|c|c|c|c|c|c|}
\hline & GDP & FDI & GDP.G & INF & Rem & Debt/GDP & NT & Crisis \\
\hline GDP & 1 & & & & & & & \\
\hline FDI & $.525^{*}$ & 1 & & & & & & \\
\hline GDP.G & .021 & -.049 & 1 & & & & & \\
\hline INF & -.098 & -.419 & -.319 & 1 & & & & \\
\hline Rem & $.840^{* *}$ & $.556^{* *}$ & .062 & -.171 & 1 & & & \\
\hline Debt/GDP & -.396 & -.324 & .178 & -.221 & $.648^{* *}$ & 1 & & \\
\hline NT & .217 & .085 & -.340 & .091 & .112 & .187 & 1 & \\
\hline Crisis & -.001 & .087 & .115 & -.160 & .218 & -.268 & -.137 & 1 \\
\hline
\end{tabular}

* Correlation is significant at the 0.05 level (2-tailed)

** Correlation is significant at the 0.01 level (2-tailed)

Source: Compiled by the authors by using the data from: World Bank (2020). Retrieved from The World bank data Cameroon: https://data.worldbank.org/country/cameroon; IMF (2020, October). International Monetory Fund Cameroon. Retrieved from imf.org: https://www.imf.org/en/Countries/CMR; Trading Economics. (2019). Cameroon GDP. Retrieved from: https://tradingeconomics.com/cameroon/gdp; Doing Business (2020, May). Economy profile Cameroon - Doing Business 2020.

The correlation analysis, especially the Pearson correlation coefficient has multiple uses, one of which is to test the hypothesis (positive or negative relationship). Another significant benefit is to check for multicollinearity between the predictors of an econometric model. The study sidelines the multicollinearity application and focuses on depicting the relationship between FDI and GDP in Cameroon. The Pearson correlation coefficient related to FDI and GDP is positively significant $(0.525)$ at 0.05 significant levels, which means that an upwards trend in FDI tends to improve the level of national output.

Table 4

Hypothesis testing

\begin{tabular}{|l|c|c|c|}
\hline & GDP $(\boldsymbol{r})$ & $\boldsymbol{R}^{\mathbf{2}}$ & $\mathbf{1 0 0}-\boldsymbol{R}^{\mathbf{2}}$ \\
\hline FDI* & .525 & $27.5625^{*}$ & $72.4375^{*}$ \\
\hline GDP.G & .021 & 0.0441 & 99.9559 \\
\hline INF & -.098 & 0.9604 & 99.0396 \\
\hline Rem & .840 & 70.56 & 29.44 \\
\hline Debt/GDP & -.396 & 15.6816 & 84.3184 \\
\hline NT & .217 & 4.7089 & 95.2911 \\
\hline Crisis & -.001 & 0.0001 & 99.9999 \\
\hline
\end{tabular}

* Target relationship between FDI and GDP $R^{2}=(r)^{2} \cdot 100$ Source: Authors' calculations

Our findings agree with those of Stoneman, Sun, Suleiman, Ngeny (Stoneman, 1975; Sun, 2002; Suleiman, 2013; Ngeny, 2014) and confirm that about $27.6 \%\left(\mathrm{R}^{2}\right)$ of changes in Cameroon's GDP is explained by the role of FDI. Other factors predict the other $72.4 \%$ of GDP per financial year. This statistical evidence does not confirm the hypothesis that FDI does not have a positive relationship with GDP.

The oligopolistic telecommunication industry in Cameroon has only one domestic firm Cameroon Telecommunication (CAMTEL). Orange-Cameroon, MTN-Cameroon and Nextel are branches of foreign companies. They entered the economy as subsidiaries, not as joint ventures. Firms that extend their branches to foreign nations by establishing subsidiaries usually show physical presence that can be seen or notice in the ownership of tangible (physical) assets. The only method of entering the market that may not lead to physical asset ownership is franchising or licensing. These two methods are more practical in developed countries but are rarely applied in less developed countries. In some cases, establishing a joint venture is a better strategy for a developing economy but since local firms lack in resources of their own, foreign companies prefer to establish subsidiaries rather than joint ventures.

The monopolistic competitive banking sector in Cameroon is mostly dominated by subsidiaries of foreign banks. There are about 16 registered banks in Cameroon: NFC bank, Afriland bank and BICEC bank are locally owned banks. Poor technological development and capital scarcity has led to a strong positive and statistically significant correlation between FDI and GDP in Cameroon. To support the required level of employment for a developing economy such as Cameroon, it is necessary to facilitate the pro- 
cess of entering the market for foreign companies. If the nation does not have the resources or technical expertise to support industrialization, then it is better to open the door for those who can help create jobs.

FDI may have a direct and indirect effect on GDP. Its direct effect is that it supports the investment $(I)$ component of national income via the expenditure method [GDP $=C+I+G+(X-M)]$. It helps create jobs and thus provides citizens of the country with an opportunity to improve their income, which entails higher consumption $(C)$ or living standards. Subsidiaries of foreign companies such as MTN-Cameroon and Ecobank Cameroon have indirect tax obligations to the government and serve as a source of government revenue and support government expenditure $(G)$. The end product of the manufacturing firms can be exported $(X)$ to other nations while raw materials are imported $(M)$ from other countries. The discovered effect accounts for the $27.6 \%$ explanatory power of FDI in relation to GDP.

\section{Conclusions}

We found a strong correlation between FDI and GDP in Cameroon for a 21-year period. In other words, the more open is Cameroon to FDI, the larger is its GDP. This result is supported by the double effect of FDI on the national economy: FDI directly affects the investment component of GDP, but it also influences economic growth indirectly. Foreign firms in Cameroon can support trade and even balance of payment, which indirectly influences the export and import component of GDP. Foreign subsidiaries, both solely owned or joint ventures, pay indirect taxes to the government and thus influence government spending.

Cameroon's economy has suffered a significant damage after the COVID-19 pandemic and the uprising in Southern Cameroon. Production and economic activities have either been interrupted or disrupted. Another threat to FDI in Cameroon is the instability in its two English-speaking regions. Political instability is known to discourage foreign investment: in most cases, some of the existing multinational firms either wind down their operations or close down altogether if the war persists. In the case of Cameroon, however, the war does not encompass the whole country and is fought mostly in the two English-speaking regions. The government should address such problems as military conflicts and outbreaks of diseases in order to reduce political instability and make their countries more attractive to FDI. A fall in FDI (withdrawal of foreign subsidiaries) may reduce employment, government revenue and industrialization. If the political and epidemiological situation in Cameroon improves, the impact of FDI on GDP may be tremendous.

Our findings can be used for developing policies and strategies for attracting FDI to $\mathrm{Ca}$ meroon. The country has the potential to become an emerging economy. The government should be able to work towards enhancing the standards of living of Cameroonians and business climate, to fight corruption, put measures in place for good governance so that every citizen could get a fair share of the national cake. It is clear that if the situation remains unchanged, it may be difficult for the country to become an emerging economy by 2035 .

\section{References}

Abala, D.O. (2014). Foreign direct investment and economic growth: An empirical analysis of Kenyan data. DBA Africa Management Review, 4(1), 62-83.

Acemoglu, D. (2006). Economic Origins of Dictatorship and Democracy. New York: Cambridge University Press.

Agwanda, B.N. (2020). Cameroon and the Anglophone Crisis. In The Palgrave Encyclopedia of Peace and Conflict Studies (pp. 1-11). Cham: Palgrave Macmillan .

Agya, A. (2014). Effect of foreign direct investment on China economic growth: a Granger Causality approach . IOSR Journal of Economics and Finance, 2(4), 56-63. doi: 10.9790/5933-0245663

Ajayi, S.I. (2006). Foreign Direct Investment in Sub-Saharan Africa: Origins, Targets, Impact and Potential., Nairobi, Kenya. African Economic Research Consortium.

Alam, A., \&. Z. (2013). Determinants of foreign direct investment in OECD member countries. Journal of Economic Studies, 40 (4), 515-527. 
Arafatur., R. \&. (2015). Effects of Foreign Direct Investment on GDP: Empirical Evidence from Developing Country. Advances in Economics and Business, 3(12), 587-592. doi: 10.13189/ aeb.2015.031207

Asiedu, E. (2002). On the Determinants of Foreign Direct Investment to Developing Countries: Is Africa Different? World Development, 30(1), 107-119. doi: 10.1016/S0305-750X(01)00100-0

Bayar, Y. (2014). Savings, foreign direct investment inflows and economic growth in emerging Asian economies. Asian Economic and Financial Review, 17.

Chakrabarti, A. (2001). The Determinant of Foreign Direct Investment: Sensivity Analysses of Cross-Country Regression. Kyklos, 54(1), 89-114. Retrieved from: https://www.doingbusiness.org/ content/dam/doingBusiness/country/c/cameroon/CMR.pdf (accessed: 07.12.2020).

Dunning, J.H. (2000). The eclectic paradigm as an envelope for economic and business theories of MNE activity. International Business Review, 9(2), 163-190.

Faruk, M. (2012). The effect of FDI to accelerate the economic growth of Bangladesh and some problems and prospects of FDI. Asian Business Review, 2(4), 7.

Forgha, N. G. (2009). Foreign Direct Investment and Economic Performance in Cameroon. International Review of Business Research Papers, 5(1), 55-69.

Gupta, D. \&. (2015). Foreign direct investment and economic growth in India: an econometric approach. Journal of Management Sciences and Technology, 2(3), 6-14.

Hakizimana, J. (2015). The Relationship between Foreign Direct Investment (FDI) and GDP Per Capita in Rwanda. Retrieved from: https://papers.ssrn.com/sol3/papers.cfm?abstract id=2598413 (accessed: 07.12.2020).

Hassen, S. \&. (2012). Foreign direct investment (FDI) and economic growth: an approach in terms of cointegration for the case of Tunisia . Journal of Applied Finance and Banking, 2(4), 193-207.

Kang., Z. \&. (2011). Foreign direct investment and economic growth in Cameroon. $2^{\text {nd }} I n-$ ternational Conference on Artificial Intelligence, Management Science and Electronic Commerce (pp. 1135-1139). Dengleng: AIMSEC.

Nadeem, I.N. (2014). Impact of Foreign Direct Investment (FDI) on GDP: A Case Study from Pakistan. International Letters of Social and Humanistic Sciences, 16, 73-80.

Naveen, D. \&. (2020). Effects of COVID-19 on business and research. Journal of Business Research, 117. doi: 10.1016/j.jbusres.2020.06.008

Ngeny, K.L. (2014). Impact of foreign direct investment volatility on economic growth in Kenya. EGARCH Analysis . Science Publishing Group, 3(4), 50-61.

Simpeh, K. (2019). The Anglophone problem: an analysis of the anglophone crisis in cameroon. Theories and analysis of conflict, peace and security (pp. 1-5). Accra: Kofi Annan International Peacekeeping Training Centre (KAIPTC).

Stoneman, C. (1975). Foreign Capital and Economic Growth. World Development, 3(1), 11-23.

Suleiman, N.K. (2013). Foreign Direct Investments (FDI) and Economic Growth: Empirical Evidence from Southern Africa Customs Union (SACU) Countries . International Journal of Economics and Management, 7(1), 136-149.

Suliman, A. \&. (2009). Human Capital Development, War and Foreign Direct Investment in Sub-Saharan Africa. Oxford Development Studies, 37(1), 47-61.

Sun, X.L. (2002). Foreign direct investment and economic development what do the states need to do? Capacity Development Workshops and Global Forum on Reinventing Government on Globalization. Role of the State and Enabling Environment, Marrakech, Morocco.

Wakyereza, R. (2017). The impact of foreign direct investment on economic growth . Employment and Poverty Reduction in Uganda, 383.

Yusuf, H.S. (2020). The role of foreign direct investment, financial development, democracy and political (in)stability on economic growth in West Africa. International Trade, Politics and DePolitics and Development, 4(1), 27-46. 


\section{Information about the authors}

Levis Petiho Numbu - PhD student in Economics, Graduate School of Economics and Management, Ural Federal University (19 Mira Str., 620002 Ekaterinburg, Russia), Gadget Zone 237 (Yaounde, Cameroon); e-mail: tresor199494@gmail.com

Zhanna S. Belyaeva - PhD, Associate Professor, Graduate School of Economics and Management, Ural Federal University (19 Mira Str., 620002 Ekaterinburg, Russia); e-mail: zh.s.belyaeva@urfu.ru

ARTICLE INFO: received July 17, 2021; accepted September 10, 2021

\section{Информация об авторах}

Петихо Нумбу Левис - аспирант, Институт экономики и управления, Уральский федеральный университет (Россия, 620002, Екатеринбург, ул. Мира, 19); Gadget Zone 237 (Яунде, Камерун); e-mail: tresor199494@gmail.com

Беляева Жанна Сергеевна - кандидат экономических наук, доцент, Институт экономики и управления, Уральский федеральный университет (Россия, 620002, Екатеринбург, ул. Мира, 19); e-mail: zh.s.belyaeva@urfu.ru

ИНФОРМАЦИЯ О СТАТЬЕ: дата поступления 17 июля 2021 2.; дата принятия к печати 10 сентября 2021 г. 